\title{
PEREMPUAN DAN ISU LINGKUNGAN (Analisis Pemberitaan di Media Nasional dan Lokal tahun 2014-2017)
}

\author{
Netty Dyah Kurniasari \\ Universitas Trunojoyo Madura \\ Email:nettyutm@gmail.com
}

\section{ABSTRAK}

Perempuan selama ini selalu digambarkan sebagai pihak yang termarginalkan. Berbagai macam kajian dan penelitian tentang gambaran (representasi) perempuan dalam media selalu menempatkan perempuan sebagai obyek. Media bisa mengkonstruksi realitas yang terjadi sehingga mempengaruhi persepsi khalayak. Penelitian ini bertujuan untuk mengetahui bagaimana media menggambarkan berita tentang perempuan dan isu lingkungan. Metode yang dipilih yaitu tekstual analisis dengan menganalisis teks yang ada pemberitaan tentang perempuan dan isu lingkungan. Media yang dipilih yaitu Kompas, Tempo, TribunNews, Antara dan Radar Madura (mewakili media lokal). Berita yang dipilih mulai tahun 2014 dengan alasan karena berita tentang isu lingkungan di Madura banyak diliput Radar Madura pada tahun 2014. Hasil penelitian menunjukkan bahwa mayoritas semua media menggambarkan perempuan sebagai sebagai obyek (korban), pihak yang selalu minta bantuan dan tidak punya inisiatif untuk mengatasi permasalahan. Sedangkan laki-laki digambarkan sebagai pihak pencari dan pemberi solusi. Namun, media nasional seperti Kompas cenderung menggambarkan perempuan seimbang (sebagai obyek dan subyek). Sebaliknya, media lokal (Radar Madura) semuanya menggambarkan perempuan sebagai obyek pencerita yang tujuan akhirnya untuk menaikkan nilai berita.

Kata kunci : Perempuan, Lingkungan, Media 


\section{ABSTRACT}

Women have always been described as marginalized. Various studies and research on the image (representation) of women in the media always put women as objects. Media can construct the reality that occurs so as to affect the perception of the audience. This study aims to find out how the media describes news about women and environmental issues. The chosen method is textual analysis by analyzing existing text on women and environmental issues. The selected media are Kompas, Tempo, TribunNews, Antara and Radar Madura (representing local media). News selected from the year 2014 on the grounds because the news about environmental issues in Madura many covered Radar Madura in 2014. The results showed that the majority of all media describe women as the object (victims) who always ask for help and do not have the initiative to overcome problems. While men are described as the problem solver. However, national media such as Kompas tend to describe balanced women (as objects and subjects). In contrast, local media ( Radar Madura) all portray women as objects of narrators whose ultimate purpose is to raise the value of news.

Keywords: Women, Environment, Media

\section{A. Pendahuluan}

Media mempunyai kemampuan untuk memilih dan menekankan isu mana yang dianggap penting dan tidak penting atau lebih dikenal dengan agenda setting. Media massa membuat tekanan pada isu tertentu dengan mengangkat public image dan secara konstan menghadirkan obyek yang mensugesti individu untuk berpikir, mengetahui dan merasakan tentang suatu (Kurniasari,2015). Sebuah isu atau peristiwa masuk dalam kategori news values atau mengandung nilai berita jika berita yang memiliki dampak (efek) bagi hajat hidup orang banyak. Contohnya adalah berita tentang bencana. Media sering meliput berita bencana yang mengakibatkan banyak korban diantaranya gambaran tangisan korban bencana dan penderitaan korban.

Berita bencana termasuk bagian berita lingkungan. Problematika lingkungan berhubungan dengan pihak pihak yang menjadi korban baik lakilaki maupun perempuan. Kehancuran lingkungan seringkali disebabkan oleh penghancuran dan pemanfaatkan lingkungan yang tidak mempedulikan kelestariannya. Alam (lingkungan) menjadi hancur, rusak oleh ulah sekelompok orang yang tidak bertanggung jawab. Menjawab permasalahannya ini, muncullah gerakan yang dinamakan ekofeminisme. 
Ekofeminisme berpandangan lingkungan dan perempuan mempunyai posisi yang sama. Lingkungan dan perempuan adalah kelompok marginal yang tidak mendapat tempat dan kurang menguntungkan (Sukmi, 2014:301). Ekofeminisme adalah sebuah gerakan sosial yang mengarah pada hubungan antara ekologi dan feminism. Asumsi gerakan ini adalah pengelolaan alam seharusnya memperhatikan berbagai aspek seperti lingkungan hidup, demokrasi, hak asasi manusia dan ketimpangan gender. Hukum patriarkhi dan pengelolaan lingkungan adalah variabel yang berdampingan sejajar (Sukmi, 2014:301). Lebih lanjut, pengelolaan lingkungan yang tidak melibatkan perempuan hanyalah akan membuat perempuan-perempuan menjadi korban dari kerusakan lingkungan (Sukmi, 2014:301).

Dalam hubungannya dengan pemberitaan, media merupakan alat untuk memproduksi dan atau mereproduksi sebuah wacana/peristiwa. Dalam dunia media, pemberitaan melibatkan berbagai macam kepentingan yaitu pemilik modal, redaktur dan reporter. Perempuan, dalam berbagai media selalu digambarkan sebagai objek pemberitaan baik dalam iklan, sinetron dan lainnya, tidak terkecuali dalam pemberitaan bencana dan lingkungan. Pada pemberitaan bencana misalnya, perempuan ditampilkan menangis supaya berita tersebut tampak lebih bernilai. Akan tetapi dalam pembahasan tentang bagaimana seharusnya penanganan bencana, perempuan seringkali tidak dilibatkan. Media, dalam peliputan bencana masih menganggap perempuan sebagai obyek. Dalam hal ini wajah perempuan selalu digambarkan sebagai pihak yang selalu minta bantuan, menuntut diberi bantuan dan belas kasihan (Sukmi, 2014).

Kajian tentang perempuan dalam pemberitaan bencana, telah dilakukan antara lain oleh Diana Patricia Manulong. Penelitian Diana lebih memfokuskan pada bagaimana representasi agenda media dalam surat kabar nasional (Manulong, 2012). Kurniawan (2006) juga meneliti tentang media massa dan lingkungan. Fokus penelitiannya menitikberatkan pada analisis isi pemberitaan media massa tentang lingkungan dan implikasinya terhadap kebijakan penegelola lingkungan di Kabupaten Bangka. Penelitian lain tentang isu lingkungan dilakukan oleh Subarkah dan Anggit Wicaksono (2014) dengan fokus pada perlawanan masyarakat Samin (Sedulur Sikep) atas Kebijakan Pembangunan Semen Gresik di Sukolilo Pati

Beberapa penelitiam yang telah ada mayoritas belum memfokuskan pada bagaimana perempuan dan isu lingkungan digambarkan di media cetak. Dengan demikian menjadi penting untuk mengkaji bagaimana media melalui 
pemberitaannya menggambarkan perempuan dan isu lingkungan. Media yang dipilih yaitu media nasional dan media lokal dengan isu terpilih berupa bencana kekeringan. Isu ini dipilih karena hampir semua kota di Indonesia mengalami kekeringan sehingga berdampak pada kekurangan air bersih. Di provinsi Jawa Timur, terdapat empat belas kabupaten yang mengalami kekeringan, namun yang paling parah adalah Madura (Kompas.Com, 16 September 2013). Selain itu alasan pemilihan isu kekeringan karena merupakan salah satu target Sustainable Development Goals (SDG). Isu krisis air menempati posisi nomor satu dalam Forum Ekonomi Dunia sebagai tantangan global yang akan dihadapi dalam satu dekade mendatang. Selain isu bencana kekeringan, salah satu isu nasional tentang perempuan dan lingkungan tergambar dalam aksi petani Kendeng yang menentang pembangunan pabrik semen. Isu tersebut bahkan menjadi trending topic di 2016 akhir sampai 2017 awal.

Penelitian ini menggunakan penelitian kualitatif yang meneliti gambar, teks, simbol dari konteks sosial tertentu. Metode kualitatif adalah metode analisis integratif untuk mengidentifikasi, menemukan, mengolah dan menganalisis dokumen untuk memahami makna atau signifikansi (Kurniasari, 2011). Ada beberapa hal yang harus diperhatikan oleh seorang peneliti ketika melakukan analisis isi kualitatif yaitu context, process dan emergence. Contect atau situasi sosial seputar dokumen (teks) yang diteliti. Kedua adalah process yaitu bagaimana suatu produksi media atau isi pesan dikreasi secara actual dan di organisasikan secara bersama (Kurniasari, 2011). Tahap yang ketiga adalah emergence yaitu pembentukan secara bertahap (gradual) dari makna sebuah pesan melalui interpretasi (pemahaman) (Kurniasari, 2011). Model yang digunakan adalah model Sara Mills yang menunjukkan bagaimana teks bias dalam menggambarkan (menampilkan) perempuan (Kurniasari, 2011). Model ini berguna untuk menganalisis hubungan bahasa kaitannya dengan ideologi. Model ini menekankan bagaimana perempuan selalu diposisikan sebagai pihak yang marginal dibandingkan laki-laki. Posisi aktor ditampilkan dalam teks juga diulas dalam model ini dan bagaimana pendengar dan pencipta ditampilkan dalam teks. Mills membagi menjadi dua bagian yaitu 1) posisi subyek-obyek, 2) posisi pendengar (Kurniasari,2011). Posisi subyek-obyek menganalisis siapa yang menjadi obyek pencerita dan menjadi subyek pencerita. Bagaimana satu kelompok, pihak, gagasan, orang ditampilkan dengan cara tertentu. Selanjutnya adalah posisi pendengar yaitu bagaimana bahasa yang digunakan ikut mempengaruhi persepsi pendengar dalam sebuah teks (Kurniasari,2011) 


\section{B. Pembahasan}

Bagi media massa, isu adalah sesuatu yang penting. Dengan adanya isu (yang kemudian diturunkan dalam sebuah pesan berita), media bisa membuat wacana atau menjadikan sesuatu yang penting dalam masyarakat. Kemunculan sebuah pesan berita tidak dapat dilepaskan dari kepentingan pemilik media (Sukmi, 2014). Salah satu tema yang dianggap menjual di media adalah berita perempuan. Perempuan dalam media seringkali digambarkan sebagai alat komersialisasi dalam iklan atau dalam berita termasuk bencana lingkungan. Perempuan dianggap sebagai komoditas yang layak dijual dan 'obyek jualan' yang dianggap bisa menambah nilai berita (Sukmi,2014). Dalam isu lingkungan dan bencana, perempuan juga dijadikan daya tarik untuk menambah nilai berita. Perempuan dalam berita bencana seringkali digambarkan menangis, meminta bantuan dan sebagai pihak yang menuntut untuk diberi bantuan, uluran tangan dan belas kasihan (Sukmi, 2014). Visualisasi perempuan dengan penderitaan menjadi daya tarik untuk menaikkan nilai berita. Hal sebaliknya terjadi pada laki-laki. Laki-laki digambarkan sebagai pihak yang memberi bantuan, memberi inisiatif solusi dan sebagai subyek pencerita.

Berita tentang perempuan dan isu lingkungan yang menjadi obyek penelitian total berjumlah sepuluh (10). Berikut ringkasan masing-masing berita:

Tabel 1: Penggambaran Laki-Laki dan Perempuan dalam Pemberitaan Bencana

\begin{tabular}{|c|c|c|c|c|}
\hline \multirow{3}{*}{$\begin{array}{c}\text { No } \\
1\end{array}$} & \multirow[t]{2}{*}{ Berita } & \multicolumn{2}{|l|}{ Media } & $\begin{array}{l}\text { Posisi Perempuan dan } \\
\text { Laki-Laki }\end{array}$ \\
\hline & & Radar & & $\begin{array}{llll}\text { Laki-laki } & \text { sebgai } & \text { subyek yang } & \text { menguasai }\end{array}$ \\
\hline & $\begin{array}{l}\text { Tujuh Desa Alami } \\
\text { Kekeringan }\end{array}$ & $\begin{array}{l}\text { Madura Edisi } \\
\text { Agustus } 2014\end{array}$ & 1 & $\begin{array}{l}\text { keadaan.Laki-laki dalam berita tersebut adalah pencari dan } \\
\text { pemberi solusi dari permasalahan kekeringan }\end{array}$ \\
\hline \multirow[t]{2}{*}{2} & Cara Warga & Radar & & Perempuan menjadi obyek pencerita dalam berita. \\
\hline & $\begin{array}{lr}\text { Karang } & \text { Penang } \\
\text { Sokobanah } & \text { Penuhi } \\
\text { Kebutuhan } & \text { Air } \\
\text { Bersih'. } & \\
\end{array}$ & $\begin{array}{l}\text { Madura, Edisi } \\
\text { Oktober } 2014\end{array}$ & 16 & $\begin{array}{l}\text { Penderitaan dan perjuangan perempuan dalam mencari } \\
\text { sumber mata air dijadikan kekuatan dalam berita tersebut } \\
\text { untuk membuat berita tersebut menarik. }\end{array}$ \\
\hline \multirow[t]{2}{*}{3} & Wartawan & Radar & & Gambar perempuan yang mengantri dengan \\
\hline & $\begin{array}{l}\text { Bantu Korban } \\
\text { Bencana } \\
\text { Kekeringan. }\end{array}$ & $\begin{array}{l}\text { Madura, Edisi } \\
\text { November } 2014 .\end{array}$ & 3 & $\begin{array}{l}\text { membawa timba air dan jerigen air ditampilkan menonjol } \\
\text { dan menjadi daya tarik (nilai jual) berita. }\end{array}$ \\
\hline 4 & $\begin{array}{l}\text { Warga } \\
\text { Tujuh Desa Alami } \\
\text { Kekeringan. }\end{array}$ & $\begin{array}{l}\text { Radar } \\
\text { Madura, } 1 \text { Agustu } \\
2014\end{array}$ & & $\begin{array}{l}\text { Perempuan ditampilkan sebagai pihak yang } \\
\text { menderita, bersusah payah mengangsu air. }\end{array}$ \\
\hline 5 & $\begin{array}{l}\text { Banjir di } \\
\text { Sampang, Risma } \\
\text { Kirim Bantuan Dua } \\
\text { Truk }\end{array}$ & $\begin{array}{r}\text { Tempo } \\
\text { Februari } 2016\end{array}$ & 29 & $\begin{array}{l}\text { Kebutuhan-kebutuhan khusus perempuan } \\
\text { seperti pembalut, susu bayi belum menjadi prioritas } \\
\text { bantuan. Berita di atas juga bias ketika media hanya } \\
\text { mewawancarai laki-laki saja. Ketika hanya wawancara } \\
\text { laki-laki, maka perspektif perempuan tidak hadir. }\end{array}$ \\
\hline
\end{tabular}


Perempuan dan Isu Lingkungan ...

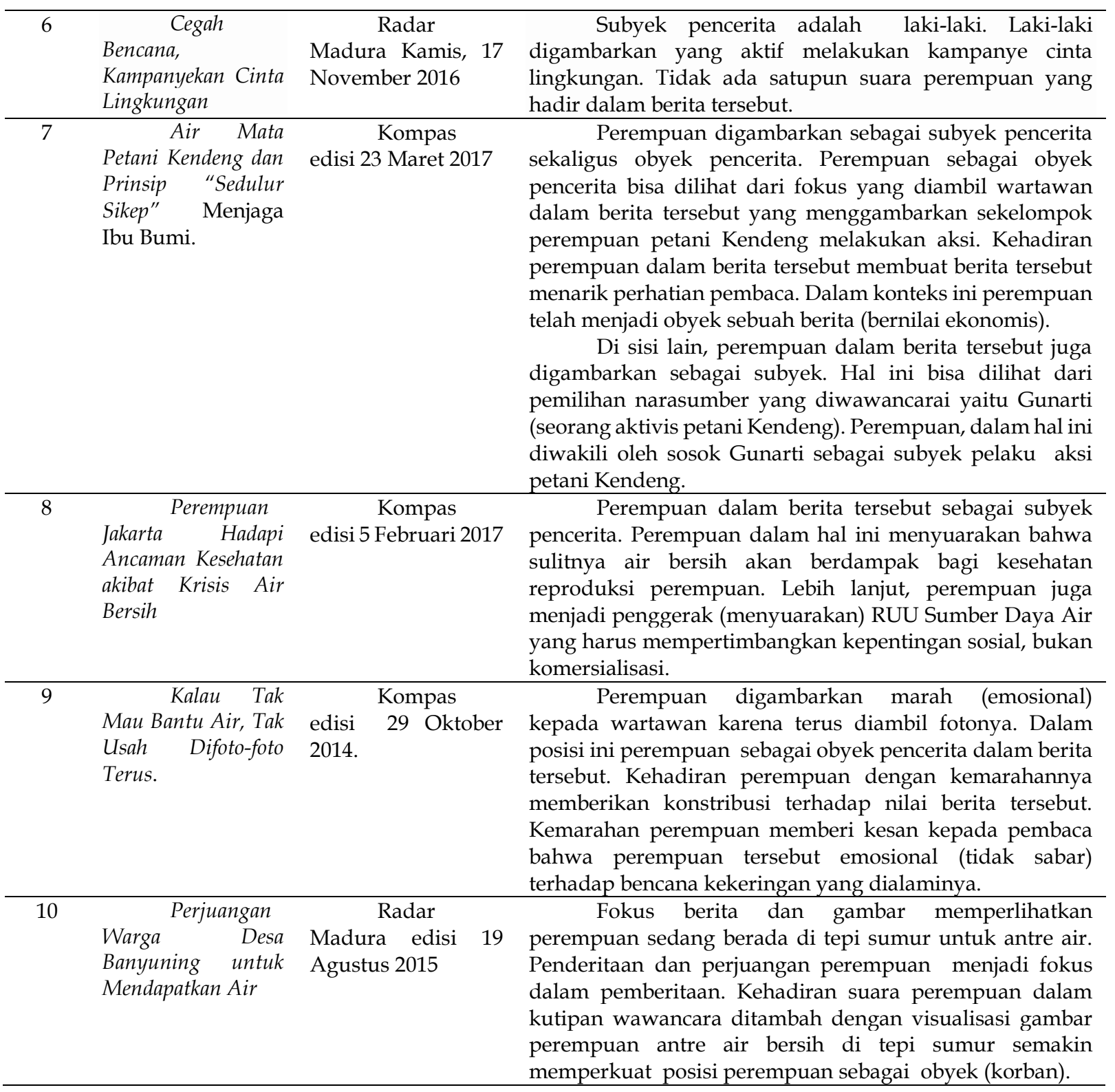

\section{Laki-Laki sebagai Subyek dalam Pemberitaan}

\section{a. Laki-laki Sebagai Pencari Solusi Bencana}

Radar Madura edisi 1 Agustus 2014 menurunkan berita tentang tujuh desa di Madura yang mengalami kekeringan. Radar mewawancarai warga untuk diminta pendapatnya terkait kekeringan tersebut. Dari beberapa kutipan yang diambil Radar Madura pihak yang diminta untuk mencari solusi sebagian besar adalah laki-laki sebagaimana tergambar dalam kutipan wawancara berikut:

'Mat Limbang, mengatakan, warga berharap ada penanganan jangka panjang untuk mengatassi kekeringan, yakni berupa pengeboran di desa rawan kekeringan. (Mat Limbang, 43, Radar Madura, 2014) 
Selain wawancara dengan Mat Limbang, Pihak Radar Madura juga mewawancarai Ahmad Wardi:

'Pemerintah harus aktif mencari solusi. Sebab, ketika kekeringan warga pontang-panting mencari air. Selain itu biaya angkut juga biaya untuk membeli air'(Ahmad Wardi,34, RadarMadura 2014)

Dalam berita diatas, Radar Madura menempatkan laki-laki sebagai subyek yang menguasai keadaan. Laki-laki dalam berita tersebut digambarkan pencari dan pemberi solusi dari permasalahan kekeringan. Selain itu, tampak dalam berita tidak hadir suara perempuan atau pendapat yang berasal dari perempuan untuk mencari solusi tersebut. Laki-laki digambarkan sebagai subyek dan pencari solusi atas permasalahan kekeringan tidak terlepas dari konstruksi masyarakat bahwa laki-laki adalah kepala rumah tangga yang bertanggungjawab untuk memenuhi nafkah keluarganya sedangakn perempuan adalah yang dinafkahi. Selain itu ada kontruksi bahwa laki-laki dianggap rasional sedangklan perempuan emosional. Sehingga laki-laki diharapkan lebih bisa memberi solusi.

\section{b. Laki-laki yang Aktif Kampanye Cinta Lingkungan}

Radar Madura edisi Kamis, 17 November 2016 menurunkan pemberitaan tentang upaya yang dilakukan kelompok pecinta lingkungan. Kelompok tersebut antara lain Lembaga Penanggulangan Bencana dan Perubahan Iklim Nahdlatul Ulama (LPBI NU), Unit Kegiatan Mahasiswa (UKM) (UKM) Ghubatras Univ. Trunojoyo Madura. Akan tetapi semua aktivias pecinta lingkungan tersebut semuanya laki-laki. Dari LPBI NU diwakili oleh Muhammad Moh. Hasan. Sedangkan dari Unit Kegiatan Mahasiswa (UKM) Ghubatras UTM diwakili oleh Subhan Fajar Sidik. Tidak tampak perwakilan perempuan dari kelompok pecinta lingkungan tersebut sebagaimana terlihat dalam gambar berikut:

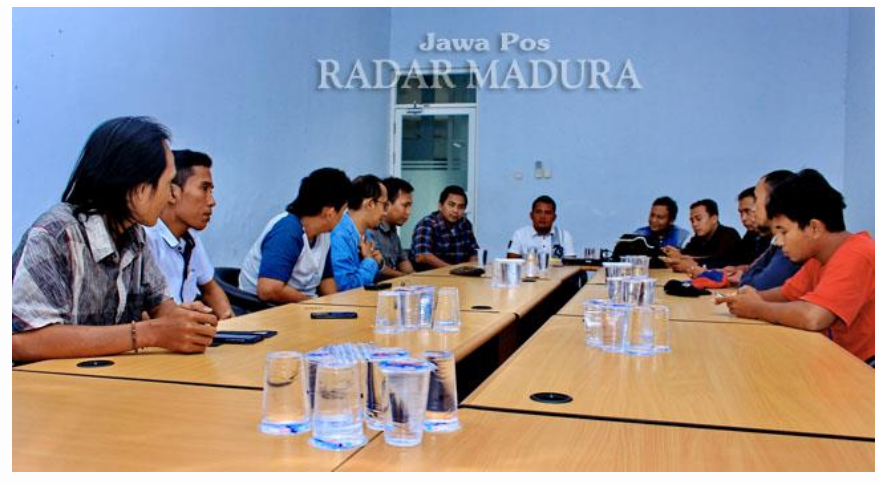

Gambar 1 : Aktivis LPBI NU dan UKm Ghubatras UTM berdiskusi dengan kru Jawa Pos Radar Madura, Rabu (16/11/2016) 
Dalam berita tersebut, subyek pencerita adalah wartawan yang dalam hal ini mewakili laki-laki. Hal ini bisa dilihat dari peran yang dilakukan oleh lakilaki dalam berita tersebut. Laki-laki digambarkan yang aktif melakukan kampanye cinta lingkungan. Tidak ada satupun suara perempuan yang hadir dalam berita tersebut.

\section{Perempuan Sebagai Subyek dalam Pemberitaan \\ a. Pencari Sumber Mata Air}

Dalam berita yang berjudul 'Cara Warga Karang Penang Sokobanah Penuhi Kebutuhan Air Bersih'Radar Madura memilih gambar pendukung warga yang mayoritas didominasi ibu-ibu sedang mandi di embung. Gambar jelasnya bisa dilihat di bawah ini:

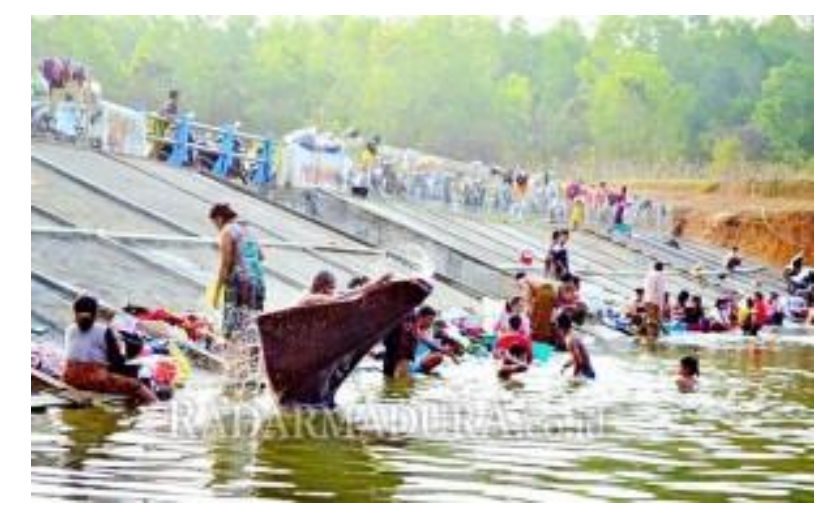

Gambar 2: warga dari enam desa mandi di salah satu embung yang terletak di Desa Tlambah

(Sumber : Radar Madura 16 Oktober 2014)

Dari gambar di atas tampak bahwa perempuanlah yang merasakan dampak besar ketika tidak ada air.Perempuan yang sebagian besar harus berjalan kaki mencari sumber mata air. Hal ini karena kebutuhan untuk memasak, mencuci sebagian besar dibebankan kepada perempuan. Sehingga ketika tidak ada air, maka dampak bagi perempuan sangat besar sekali.

Radar juga mewawancarai perempuan yaitu Ibu Maryamah warga desa Karang Penang untuk menceritakan perjuangannya hilir mudik mencari sumber air.

'Saya ke embung bersama anggota keluarga yang lain, sambil membawa pakaian yang sudah seminggu tidak dicuci. Jarak rumah ke embung cukup jauh, sekitar 15 kilometer' (Maryamah, Radar Madura 2014)

Sangat jelas dalam berita tersebut yang menjadi obyek pencerita adalah perempuan. Penderitaan dan perjuangan perempuan dalam mencari sumber 
mata air dijadikan kekuatan dalam berita tersebut untuk membuat berita tersebut menarik. Perempuan dan media adalah sesuatu yang tidak bisa dipisahkan. Perempuan bagi media adalah daya tarik dan magnet luar biasa untuk menjadikan berita menjadi lebih menjual dan dibaca khalayak.

\section{b. Perempuan Pengangkut Air}

Selain di Sampang, kekeringan juga melanda Kabupaten Pamekasan yaitu di Desa Larangan Tokol, Kecamatan Tlanakan. Kemudian, sekelompok wartawan yang tergabung dalam AJP (Aliansi Jurnalis Pamekasan) memberikan bantuan kepada warga desa tersebut. Hal tersebut diceritakan dalam Radar Madura edisi November 2014. Dalam berita tersebut digambarkan bawah hanya perempuan yang antri untuk mengangkut air bantuan dari AJP. Perempuanlah yang mengantri dengan membawa timba air dan jerigen air. Hal tersebut bisa dilihat di pada gambar dibawah ini:

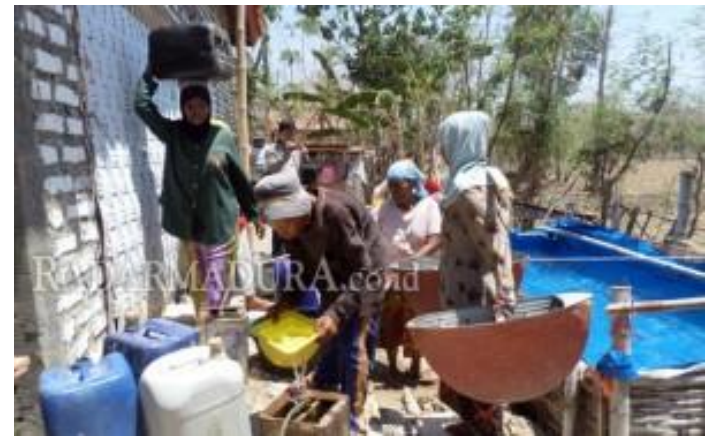

Gambar 3 : Warga Larangan Tokol, Kecamatan Tlanakan, mengangkut air bantuan AJP

Sumber : Radar Madura 3 November 2014

Selain terdapat dalam gambar edisi 3 November 2014, perjuangan perempuan pengangkut air juga dimuat di edisi 1 Agustus 2014. Dalam gambar ditampakkan bahwa perempuan yang bersusah payah naik turun mobil pick up pengangkut air. Posisi perempuan digambarkan bergelantungan di besi (kayu) seadanya yang bisa membahayakan keselamatan perempuan tersebut. Untuk jelasnya, bisa dilihat dari gambar di bawah ini:

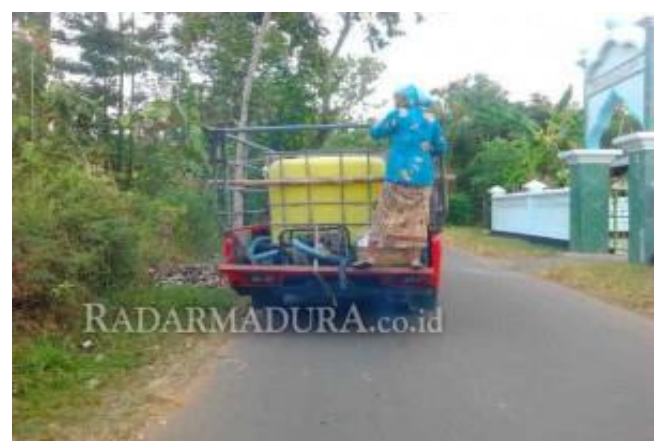

Gambar 4: Salah seorang warga mengangkut air bersih dari desa lain menggunakan mobil pick up. 
Perempuan dalam berita tersebut ditampilkan sebagai pihak yang menderita, bersusah payah mengangsu air. Pencantuman gambar perempuan yang mengangsu dan naik mobil pick up untuk mencari air membuat berita tersebut menarik pembaca untuk merasa kasihan dengan perempuan. Dalam kacamata media, perempuan dengan penderitaan memiliki nilai jual yang tinggi. Penggambaran perempuan dengan tambahan visualisasi penderitaan yang didramatisir akan membuat khalayak pembaca untuk kasihan dan akhirnya membaca (baca; membeli) media tersebut.

\section{c. Bantuan Belum Berbasis Kebutuhan Perempuan}

Dalam keadaan bencana, kebutuhan untuk perempuan dan anak lebih banyak dibandingkan dengan kebutuhan laki-laki.Perempuan misalnya butuh pembalut ketika menstruasi. Bagi perempuan yang memiliki anak bayi, maka kebutuhan akan bertambah lagi antara lain susu, , popok bayi baik kain maupun sekali pakai, selimut dan lainnya. Di beberapa pemberitaan media massa, kebutuhan khusus ini jarang diberikan. Biasanya kebutuhan yang paling banyak adalah sembako. Hal tersebut bisa dilihat dari pemberitaan Tempo edisi 29 Februari 2016 yang berjudul ‘Banjir Sampang, Risma Kirim Bantuan Dua Truk. Berbagai kebutuhan pokok itu berupa mie instan, roti, kue kering, biskuit, air mineral, baju anak-anak dan baju orang dewasa layak pakai, serta sarung' (Hariyanto, Tempo, 2016).

Pemberitaan untuk bantuan untuk korban Sampang juga dimuat di Antara edisi Maret 2016. Jenis bantuan yang diberikan kepada korban banjir bentuknya bervariasi mulai dari kesehatan, bahan makanan dan obat-obatan. Namun yang paling banyak adalah berbentuk bahan makan (makanan siap saji), sembako, mie instan, roti, kue kering, biskuit, air mineral, baju anakanak dan baju orang dewasa layak pakai, sarung. Masih jarang bentuk bantuan seperti pembalut untuk perempuan, diapers untuk bayi (anak), susu bayi dll (Antara,2016).

Dari pemberitaan tersebut, tampak bahwa bentuk bantuan bencana belum berperspektif perempuan. Dengan kata lain, kebutuhan-kebutuhan khusus perempuan seperti pembalut, susu bayi belum menjadi prioritas. Berita di atas juga bisa ketika media hanya mewawancarai laki-laki saja. Dalam berita tersebut, laki-laki menjadi subyek pencerita. Dalam hal ini dia berperan sebagai subyek penolong yang memberikan bantuan terhadap korban (baca: perempuan). Hal ini tampak dari narasumber yang dipilih untuk menjelaskan bentuk dan jenis bantuan yaitu Eko Hariyanto. 


\section{d. Perempuan "Sedulur Sikep" Menjaga Ibu Bumi}

Kompas edisi tanggal 23 Maret 2017 menurunkan pemberitaan tentang aksi yang dilakukan warga Pegunungan Kendeng. Mayoritas warga yang melakukan aksi perempuan. Hal ini bisa dilihat dari pemilihan gambar yang dipilih dimana mayoritasnya adalah perempuan. Fokus dan angle yang diambil di gambar memperlihatkan bagaimana perjungan sekelompok perempuan untuk memperjuangkan aksinya. Berikut kutipan beritanya:

' Patmi berkerudung biru (48 tahun) salah seorang petani perempuan asal kawasan Pegunungan Kendeng yang melakukan aksi mengecor kaki di depan Istana Negara, Jakarta, meninggal dunia pada Selasa (21/3/2017) dini hari.Patmi mengalami serangan jantung dan meninggal dalam perjalanan......' ( Kompas, 23 Maret 2017)

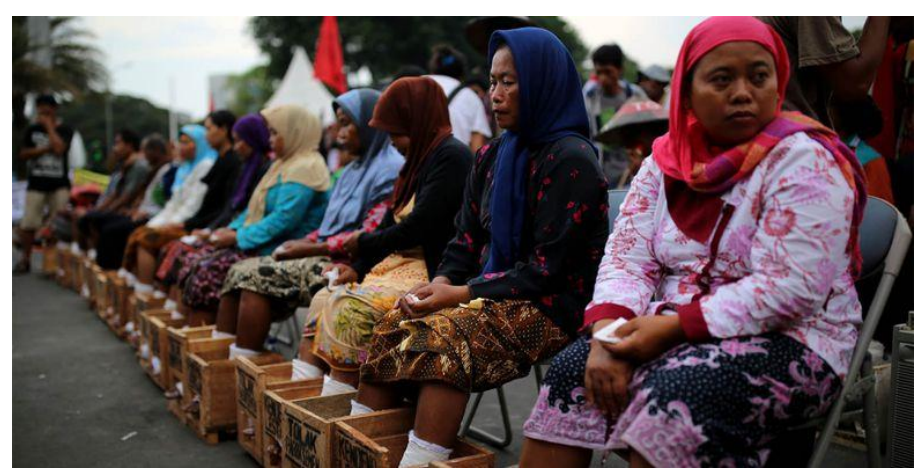

Gambar 5 : Petani Perempuan Kendeng melakukan Aksi. Kompas, 23 Maret 2017

Kompas juga mewawancarai Gunarti, perwakilan petani di Pegunungan Kendeng untuk menyampaikan protes kepada Bapak Jokowi terkait keberadaan pabrik semen yang dinilai merusak lingkungan.

Pemberitaan Kompas 23 Maret 2017 tersebut menempatkan perempuan sebagai subyek pencerita sekaligus obyek pencerita. Perempuan sebagai obyek pencerita bisa dilihat dari focus yang diambil wartawan dalam berita tersebut yang menggambarkan sekelompok perempuan petani Kendeng melakukan aksi. Kehadiran perempuan dalam berita tersebut membuat berita tersebut menarik perhatian pembaca. Dalam konteks ini perempuan telah menjadi obyek sebuah berita (bernilai ekonomis).

Di sisi lain, perempuan dalam berita tersebut juga digambarkan sebagai subyek. Hal ini bisa dilihat dari pemilihan narasumber yang diwawancarai yaitu Gunarti (seorang aktivis petani Kendeng). Perempuan, dalam hal ini diwakili oleh sosok Gunarti sebagai subyek pelaku aksi petani Kendeng dari perwakilan komunitas adat Sedulur Sikep. Mereka memegang prinsip bahwa bumi 
disamakan dengan ibu yang selayaknya harus dijaga kelestariannya. Digambarkan dalam pemberitaan:

‘Dalam setiap aksinya.... Petani Kendeng selalu melantunkan tembang Ibu Ibu Bumi. "Ibu bumi wis maringi, ibu bumi dilarani, ibu bumi kang ngadili," yang artinya "Ibu bumi sudah memberi, ibu bumi disakiti, ibu bumi akan mengadili."Tembang Ibu Bumi merupakan doa-doa yang sengaja diciptakan sebagai pengingat kepada manusia agar selalu menjaga kelestarian alam. Mereka memercayai bahwa bumi adalah seorang ibu yang harus dirawat, dijaga dan tidak boleh disakiti (Air Mata Petani Kendeng dan Prinsip "Sedulur Sikep" Menjaga Ibu Bumi. Kompas edisi 23 Maret 2017).

\section{e. Kesehatan Perempuan Terancam karena Krisis Air}

Kompas edisi 5 Februari 2017 memuat berita tentang ancaman kesehatan yang dihadapi perempuan karena krisis air bersih. Narasumber yang diwawancarai yaitu Ketua Solidaritas Perempuan Puspa Dewi. Dalam pemberitaannya, Kompas menekankan bahwa krisis air akan sangat berdampak bagi kesehatan reperoduksi perempuan. Berikut kutipan langsungnya :

"Sulitnya akses terhadap air bersih berpengaruh pada kesehatan reproduksi kaum perempuan. Setidaknya perempuan harus memenuhi kebutuhan kesehatan reproduksinya, terutama pada saat menstruasi, kehamilan dan pasca-melahirkan. Krisis air berdampak pada kehidupan perempuan. Air di Jakarta sebagian besar tidak bisa dikonsumsi karena kualitasnya jelek, berwarna dan berbau. Hal itu tentu berakibat pada kesehatan reproduksi perempuan," ujar Puspa." (Kompas, 5 Februari 2017).

Dalam pemberitaanya, Kompas juga menguraikan penjelasan yang disampaikan oleh Puspa bahwa 94\% warga memanfaatkan air dengan kualitas yang buruk. Krisis air yang dimaksud mencakup kuantitas, kualitas dan kontinuitas. Lebih lanjut, pemerintah dan DPR dalam pembahasan RUU Sumber Daya Air harus mempertimbangkan kepentingan sosial, bukan pada komersialisasi.

Dalam pemberitaan Kompas edisi 5 Februari 2017 tamnpak bahwa perempuan dalam berita tersebut sebagai subyek pencerita. Perempuan dalam hal ini menyuarakan bahwa sulitnya air bersih akan berdampak bagi kesehatan reproduksi perempuan. Lebih lanjut, perempuan juga menjadi penggerak (menyuarakan) RUU Sumber Daya Air yang harus mempertimbangkan kepentingan sosial, bukan komersialisasi. 


\section{f. Perempuan Korban Terdampak KekeringanTerlihat Emosional}

Kompas edisi 29 Oktober 2014 menurunkan berita tentang bencana kekeringan yang melanda tiga dusun yaitu Dusun Rombasan, Dusun Tengah, Dusun Kebun Sareh Desa Larangan Tokol Kecamatan Tlanakan. Dalam pemberitaan, perempuanlah yang paling terdampak akibat kekeringan tersebut. Hal ini bisa dilihat dari kemarahan perempuan bernama Sulaikah. Sulaikah nampak kesal ketika difoto dan direkam oleh wartawan. Menurutnya, dia kesal, karena wartawan hanya datang memfoto. Padahal warga lebih membutuhkan air daripada difoto. Berikut kutipan lengkapnya:

"Sulaihah, salah satu warga Dusun Rombasan mengaku kesal dirinya hanya difoto dan direkam video. Namun sampai sekarang tidak pernah ada bantuan air. Padahal warga lebih membutuhkan air daripada difoto. "Kalau tidak mau bantu air, tidak usah difoto-foto terus, Pak," kata perempuan paruh baya ini" (Kompas, 29 Oktober 2013).

Namun, setelah mendapat penjelasan dari wartawan, bahwa akan ada sejumlah wartawan yang akan memberikan bantuan air, dia langsung sumringah.Selain menguraikan kekesalan Sulaihah karena difoto terus, Kompas juga menggali lebih dalam pengalaman perempuan yang mengalami kekeringan. Perempuan itu misalnya diceritakan harus saling berebut dan mengakibatkan perkelahian karena antrian jerigen dipindah.Lebih lanjut, dalam pemberitaan juga dijelaskan, karena perempuan diberi peran domestik yaitu mencuci, memasak, dan sebagainya maka perempuanlah yang paling banyak merasakan dampak kekeringan. Salah satunya adalah warga harus menghemat air, menggunakan air bekas mencuci beras untuk mencuci piring dan alat-alat dapur lainnya.

Pemberitaan Kompas edisi 29 Oktober 2013 menceritakan perempuan yang marah (emosional) kepada wartawan karena terus diambil fotonya. Perempuan tersebut marah karena seharusnya wartawan memberikan bantuan air, bukan hanya mengambil foto. Dalam posisi ini perempuan sebagai obyek pencerita dalam berita tersebut. Kehadiran perempuan dengan kemarahannya memberikan konstribusi terhadap nilai berita tersebut. Kemarahan perempuan memberi kesan kepada pembaca bahwa perempuan tersebut emosional (tidak sabar) terhadap bencana kekeringan yang dialaminya. 
Perempuan dan Isu Lingkungan ...

\section{g. Perjuangan Perempuan Dasuk Menemukan Sumber Air}

Warga di Desa Mantajun, Kecamatan Dasuk Sumenep harus berjuang berjalan kaki sejauh lima kilometer untuk mendapatkan air bersih. Web berita Tribun News memberitakan hal tersebut pada edisi Kamis, 12 September 2013. Dalam pemberitaan tersebut Tribun mewawancarai perempuan yang bernama Surtini untuk menuturkan pengalamannya:

'Persediaan air di rumah-rumah penduduk saat ini sudah habis dan sumur warga sudah mengering' 'Sekarang sudah kemarau, dan air hujan yang kami tampung sudah habis. Terpaksa harus mencari ke daerah lain, untuk mendapatkan air bersih dengan tanpa membeli (Surtini, Trubunnews).

Warga desa biasanya memakai air hujan untuk persediaan. Air tersebut ditampung dalam sebuah tandon besar, namun sekarang persediaan air tersebut sudah habis, sehingga mereka harus mencari di tempat lain (Tribun News, Kamis 12 September 2013). Dalam pemberitaan tersebut, Tribun News selain mewawancarai perempuan, juga menampilkan visualisasi perempuan yang antri untuk mendapatkan air bersih dalam gambar 6 .

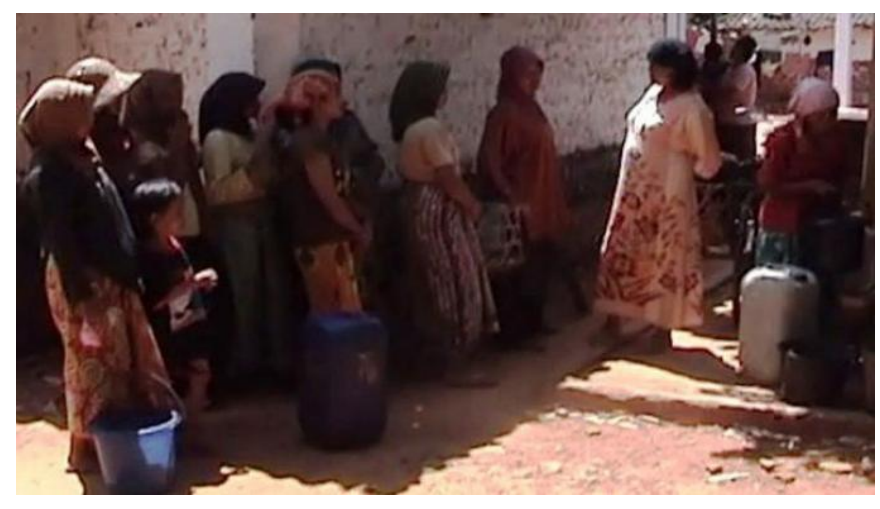

Gambar 6: Warga Desa Mantajun antri air bersih setelah berjalan 5 kilometer Sumber :TribunNews, Kamis 12 September 2013

Dari pemberitaan dan visualisasi tersebut perempuan sebagai obyek pencerita yang membuat berita tersebut menjadi menarik untuk dibaca. Berdasarkan kategori news values, berita yang mempunyai nilai berita tinggi salah satunya adalah berita tentang perempuan dan bencana yang menyebabkan penderitaan. Walaupun Tribun mewawancarai perempuan untuk diminta pendapatnya, namun dari pendapat tersebut semakin membuat posisi 
perempuan sebagai obyek terlihat. Perempuan sebagai korban terdampak paling besar dari bencana kekeringan.

\section{h. Perempuan Banyuning Ngantre di Sumur}

Radar Madura edisi 19 Agustus 2015 dalam judulnya menulis 'Perjuangan Warga Desa Banyuning untuk Mendapatkan Air'. Diberitakan bahwa 80 desa yang tersebar di 17 Kecamatan di Bangkalan mengalami kekeringan, salah satunya yaitu Dusun Langgali, Desa Banyuning Laok, Kecamatan Geger. Walaupun dalam judulnya memakai kata 'Warga', Akan tetapi dalam gambar berita tersebut yang nampak antri adalah perempuan. Perempuan dalam gambar tersebut digambarkan sedang berada di tepi sumur untuk antre air. Berikut gambar lengkapnya.

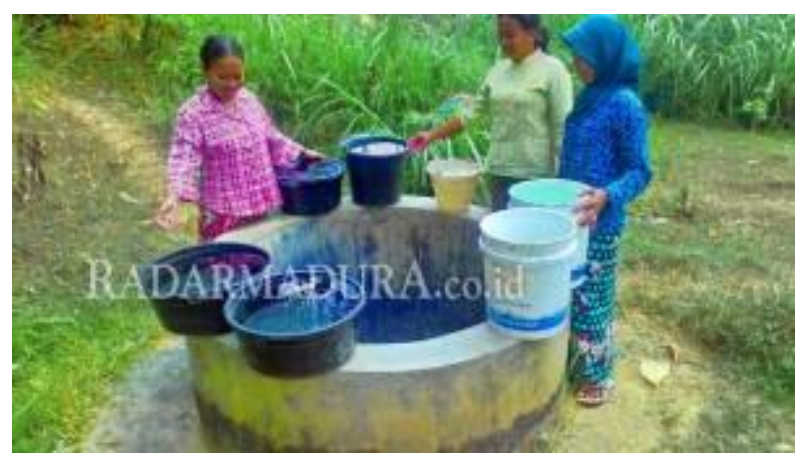

Gambar 7 : Untuk mendapatkan air, warga Dusun Langgali, Desa Banyuning Laok, Kecamatan Geger harus mencari sumur yang masih mengeluarkan air.

Sumber : Radar Madura 19 Agustus 2015

Untuk mendukung berita, Radar melakukan wawancara dengan warga, salah satunya yaitu Heny (25 tahun). Heny menyatakan bahwa pemerintah belum memperhatikan masyarakat. Warga masih harus berjuang sendiri untuk memenuhi kebutuhan sehari-hari (Radar Madura, 19 Agustus 2015). Berikut kutipan pernyataan Henny.

'Warga berharap ada bantuan dari pemerintah agar masyarakat kurang mampu bisa merasakan bantuan air bersih. Bukan kali ini saja, tapi setiap musim kemarau kami kesulitan air bersih' (Radar Madura, 19 Agustus 2015)

Dari pemberitaan diatas, nampak bahwa penderitaan dan perjuangan perempuan menjadi fokus dalam pemberitaan. Kehadiran suara perempuan dalam kutipan wawancara ditambah dengan visualisasi gambar perempuan 
antre air bersih di tepi sumur semakin memperkuat posisi perempuan sebagai obyek (korban).

Perempuan dan isu lingkungan yang ada di media massa baik nasional dan lokal sebagaimana telah diuraikan menempatkan perempuan secara garis besar sebagai obyek berita. Obyek dalam hal ini adalah perempuan dijadikan daya tarik berita tersebut. Visualisasi perempuan dibuat semenarik mungkin untuk membuat news values semakin tinggi. Perempuan dan isu lingkungan digambarkan sebagai pihak yang selalu minta bantuan, dikasihani dan tidak memiliki inisiatif untuk mencari solusi. Sebaliknya, laki-laki digambarkan sebagai pihak yang mencari solusi atas permasalahan. Hal tersebut tidak terlepas dari konstruksi masyarakat yang masih patriarkhi. Struktur media dan jumlah wartawan laki-laki di media yang lebih banyak dibandingkan perempuan juga berpengaruh terhadap isi berita. Ketika jumlah wartawan laki-laki lebih banyak di media, maka pengetahuan, pengalaman dan konstruksi laki-laki akan mendominasi isi dari pemberitaan.

Hal tersebut terjadi karena media memiliki banyak kepentingan. Isi media yang tersebar ke publik tidak terlepas dari kepentingan pemilik modal dalam dan orang-orang yang berada di balik layar tersebut. Mulai dari proses produksi, editing hingga berita tampil ke publik sangat dipengaruhi siapa yang berada di balik layar, dan di ruang-ruang redaksi inilah bias gender terjadi ( AJI, 2015). Hasil Riset AJI pada tahun 2012 menunjukkan asumsi di atas. Sedikitnya jumlah jurnalis perempuan (hanya 1:4) di ruang redaksi yang menempati posisi strategis membuat banyak media tidak memiliki sensitivitas gender. Jurnalis perempuan sering mengalami pelecehan dari rekan kerja dan narasumber hingga mengalami kekerasan. Belum lagi berhubungan dengan hak cuti haid, hak melahirkan, ruang menyusui yang tidak semua media memberikan fasilitas. Lebih lanjut, jurnalis perempuan yang bekerja di televisi sering menjadi pemanis layar, harus tampil cantik, berdandan. Konsekuensi lebih lanjut, minimnya kesadaran gender mengakibatkan pemuatan nara sumber perempuan yang memiliki kemampuan dan kompetensi lebih baik menjadi sangat terbatas (AJI, 2015)

Berdasar hal tersebut maka menjadi penting untuk memasukkan indikator kesetaraan gender di organisasi media. Beberapa langkah-langkah untuk mendorong kesetaraan gender di organisasi media antara lain (AJI, 2015) :

a. Keberimbangan gender pada level pengambil keputusan

b. Kesetaraan gender di ruang kerja 
c. Kesetaraan gender di serikat, asosiasi, klub, dan organisasi jurnalis, profesional media lain, serta badan regulator media

d. Organisasi media mendorong penerapan kode etik / kebijakan editorial yang mendukung kesetaraan gender dalam pemberitaan

e. Keberimbangan gender dalam pendidikan dan pelatihan

Dalam berita misalnya ada beberapa indikator yang harus ada dalam pemuatan berita: Pertama, proporsi perempuan dan laki-laki yang muncul, didengar dalam pemberitaan dan produksi media. Kedua, proporsi perempuan dan laki-laki yang muncul sebagai 1) juru bicara; 2) pakar; dan 3) warga biasa. Ketiga, proporsi kisah dengan stereotipe (penafsiran seksis yang terbuka atas karakteristik serta peran perempuan dan lelaki di dalam masyarakat). Keempat, proporsi kisah dengan stereotipe (penggambaran karakteristik kolot "feminin" atau " maskulin". Kelima, proporsi perempuan berbanding dengan laki-laki yang digambarkan sebagai korban (contoh korban kejahatan, konflik, bencana, kemiskinan dsb), Keenam, proporsi perempuan berbanding dengan laki-laki sebagai penyintas (yaitu, orang yang telah mampu mengatasi dan yang dapat berbagi pengalaman merugikan seperti kejahatan, konlik, bencana, kemiskinan dsb) (Aji,2015).

\section{Simpulan}

Mayoritas perempuan dalam bencana digambarkan sebagai obyek (korban), pihak yang selalu minta bantuan dan tidak punya inisiatif untuk mengatasi permasalahan. Sedangkan laki-laki digambarkan sebagai pihak pencari dan pemberi solusi. Ada sedikit perbedaan antara media nasional dan lokal dalam menggambarkan perempuan. Media nasional seperti Kompas cenderung menggambarkan perempuan seimbang (sebagai obyek dan subyek). Akan tetapi, media lokal yaitu Rasar Madura menggambarkan perempuan sebagai obyek pencerita yang tujuan akhirnya untuk menaikkan nilai berita. Sensitifitas gender para pekerja media baik jurnalis maupun pemilik modal dalam hal ini menjadi pemegang kunci pemberitaan perempuan dan isu lingkungan di media yang setara dan adil gender.

Artikel ini dapat dilanjutkan kajian untuk menghitung jumlah dan jenis berita lingkungan yang ditampilkan media. Hal ini penting untuk mengetahui apakah isu lingkungan menjadi agenda penting bagi media atau hanyalah isu tambahan. Lebih lanjut, jenis berita lingkungan yang ditulis media juga perlu dilihat, apakah hanya memberitakan dampak bencana lingkungan atau ada upaya advokasi dari media untuk penyadaran ke pembaca tentang kelestarian lingkungan. 
Perempuan dan Isu Lingkungan ...

\section{DAFTAR PUSTAKA}

AJI (Aliansi Jurnalistik Independen), 2015 , Indikator Sensitif gender Untuk Media. Aliansi Jurnalistik Independen:Jakarta.

Antara, 2016, Bantuan Banjir Sampang Berdatangan.Edisi Selasa 01 Maret 2016.

Kompas.com, 2017, Perempuan Jakarta Hadapi Ancaman Kesehatan akibat Krisis Air Bersih.Edisi 5 Februari 2017.

Kompas.com,2014, Kalau Tak Mau Bantu Air, Tak Usah Difoto-foto Terus. Kompas edisi 29 Oktober 2014.

Kompas.com, 2017, Air Mata Petani Kendeng dan Prinsip "Sedulur Sikep" Menjaga Ibu Bumi. Kompas edisi 23 Maret 2017.

Kurniasari, Netty Dyah, 2015. Agenda Setting Function (Studi Kasus Krisis Ekonomi Amarika dan Global. Jurnal Komunikasi. Vol IX No 01, Maret 2015 (95-104)

Kurniasari, 2011, Seksisme dan Seksualitas dalam Lagu Pop (Kajian terhadap Lirik Lagu 'Surti-Tejo' Menggunakan Analisis Tekstual . Jurnal Pamator Volume 4 No 1 April 2011.

Radar Madura,2015, Perjuangan Warga Desa Banyuning untuk Mendapatkan Air.Edisi 19 Agustus 2015.

Radar Madura, 2014, Warga Tujuh Desa Alami Kekeringan.Edisi 1 Agustus 2014.

Radar Madura, 2014, Cara Warga Karang Penang Sokobanah Penuhi Kebutuhan Air Bersih'. Edisi 16 Oktober 2014

Radar Madura, Warga Tujuh Desa Alami Kekeringan.Edisi 1 Agustus 2014

Radar Madura, Wartawan Bantu Korban Bencana Kekeringan.Edisi 3 November 2014.

Radar Madura, 2016, Cegah Bencana, Kampanyekan Cinta Lingkungan.Radar Madura (JPRM) Kamis, 17 November 2016

Sukmi, Sih Natalia, 2014, Bagaimana Sikap Media thd Isu Lingkungan dan Perempuan?, dalam : Dewi Candraningrum, EKofeminisme II (Narasi Iman, Mitos,Air, Tanah, Yogyakarta: Jalasutra.

S.Subarkah,2014, Perlawanan Masyarakat Samin.(Sedulur Sikep) Atas Kebijakan Pembangunan Semen Gresik Di Sukolilo Pati dalam Jurnal Ilmu Pengetahuan dan Teknologi Vol 26 No 2 (2014)

Tempo, Banjir di Sampang, Risma Kirim Bantuan Dua Truk. 29 Februari 2016

TribunNews,2013, Warga 6 Dusun di Sumenep Jalan Kaki 5 Kilometer Demi Air Bersih. Edisi Kamis 12 September 2013. 